\title{
The Conflict between Secularism and Islam in Ayad Akhtar's Disgraced (*)
}

\author{
Doaa Essam Abdel Hakim \\ Faculty of Arts - Helwan University
}

\begin{abstract}
The research examines the play, Disgraced (2012) written by the Pakistani American dramatist, Ayad Akhtar. The main research question is reflected in the title: is there a conflict between the principles of Islam and those of Secularism? The methodology followed to answer the question is analyzing the protagonist's character in the light of the concept of secularism. The play provides various definitions of secularism which are all in dire contrast to Islam. Probing into the character of Amir, an American Muslim of a Pakistani origin who renounces his faith and leads a secular life in the US, reveals that Muslims are mistreated in the American society particularly after the 9/11 events. The self-loathing Amir who hides his Islamic identity, loses his job and his wife and realizes that Muslims are unjustly treated simply because they are Muslims no matter how hard they try to get assimilated in the American society. The research reaches the conclusion that Islam and Secularism are contrasting ideologies and Muslims suffer in America because of the Western false understanding of Islam and the Islamic rejection of Secularism.
\end{abstract}

Key Words: Islam - Secularism - assimilation - self-loathing

${ }^{(*)}$ Bulletin of the Faculty of Arts Volume 79 Issue 8 October 2019 


\title{
الصراع بين الإسلام والعلمانية في مسرحية المشان لآياد أخطر
}

\begin{abstract}
يحلل البحث مسرحية المشان ( Y ب ب) للكاتب الأمريكي من أصل باكستاني آياد

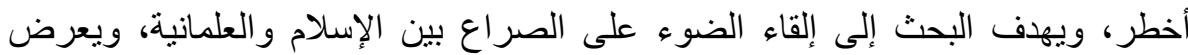

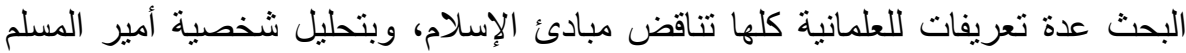

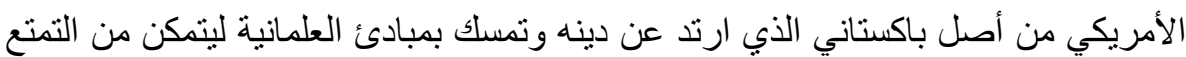

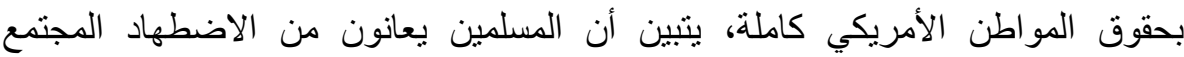

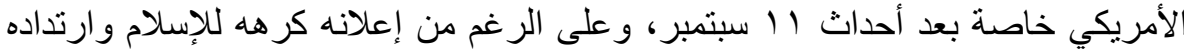

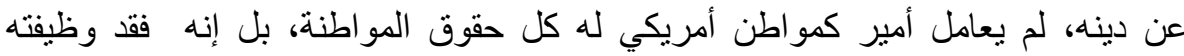

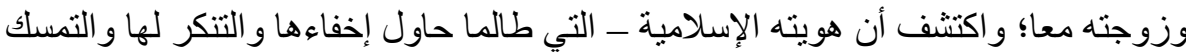

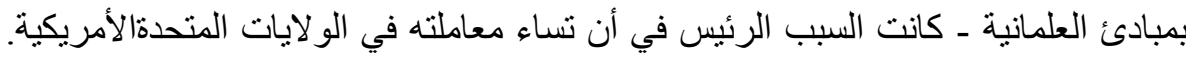

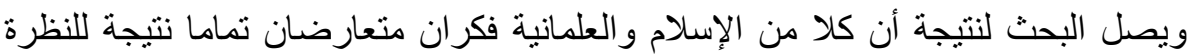
الغربية الخاطئة للإسلام ورفض الإنه الإنلام لمبادئ العلمانية.
\end{abstract}

\section{Introduction}

Disgraced (2012) is a one-act play written by the Pakistani American dramatist, Ayad Akhtar, who won the Pulitzer Prize for Drama in 2013. The play discusses critical topics such as Islamophobia, racial and religious prejudices and the identity of minorities living in the USA. The main topic discussed in this paper is the conflict between Islam and secularism in Disgraced which revolves around Amir Kapoor, a Pakistani corporate lawyer who was born in the US and who "has tried to obliterate his Pakistani roots. He has left the Muslim religion, which he castigates as primitive, and even adopted a new last name so he could pass for Indian" (Feldberg BL1). Akhtar who shares the same cultural background with his protagonist, explains that Amir is "pre-emptively trying to make himself in the eyes of the American majority - and his rejection of Islam is operating as a kind of card-carrying membership of being Western" (Nestruck par. 5). The Islamic identity does not, in Amir's 


\section{—Doaa Essam Abdel Hakim: The Conflict between Secularism and Islam 9}

point of view, help people enjoy their American citizenship. Therefore, Amir falsely believes that leading a secular life would, probably, protect him against the religious discrimination which notably increased after 9/11 events. Disgraced introduces different concepts of secularism through Amir, all of which are opposing Islam.

\section{Research questions:}

The major question of the research is: is there a conflict between Islam and secularism and how it is reflected in Ayad Akhtar's Disgraced?

That question includes three minor questions:

1. What are the different definitions of secularism?

2. What is meant by the US secularism?

3. To what extent does a self-loathing Amir reflect the contradictions between the Islamic laws and the principles of secularism?

\section{Method of Research}

The questions posed in the 'research questions section' will be answered through a sociological approach to Ayad Akhtar's Disgraced. The play will be analyzed in the light of the concept of secularism and its relationship with Islam. The internal as well as the external conflicts which Amir, the protagonist, suffers from will be analyzed carefully.

\section{Analysis}

'Secularism', "first used by the British writer George Jacob Holyoake in 1851" (Ebrahinian 110) is difficult to define but the variant definitions revolve around the relationship between religion and political, public or personal life. In his "Secularism and the Supreme Court" (1999), George Dent argues that "secularists purported to rely on fact and reason alone. They objected to religion in public debate because it rests on faith and cannot be tested by fact or reason" (1). Secularism, according to Dent, rejects religion in 
general as something abstract which is in dire contrast to matter. Foregrounding matter, secularists neglect soul, the most indispensable part of religion: "Religion is thus depreciated in favour of "matters that can be analyzed empirically" (Dent 1). Dent's argument goes in line with Kenneth Wald's concept of 'desacrilization' as one of the definitions of secularism. Wald defines 'desacrilization' as "the tendency to explain the universe in terms of material reality rather than supernatural force" (5). In Disgraced, it is not accidental that Amir is a materialistic character whose wife, Emily, describes him as "always talking numbers" (iii. 41). She also wonders, when Amir says: "selling's not everything": "Selling's not everything? You really believe that?" (i. 5) Amir's expensive shirts also reflect a materialistic mind:

JORY.People do not stop talking about your shirts at the office.

AMIR. Really?

JORY.Sarah was joking you must spend half what you make on shirts.

EMILY. Wouldn't be far from the truth. Charvet always (iii. 42).

It is significant to note that though Amir adheres to the materialistic world to pass for a good American, Isaac, the Jew, draws a link between Amir in his expensive shirts and Pareija, Velizquez's Moorish slave whose picture Emily imitates by painting her South-Asian husband. Isaac says: "so there you are, in your six-hundred-dollar Charvet shirt, like Velizquez's brilliant apprentice-slave in his lace collar, adorned in the splendors of the world..." (iii. 43). In contrast to her husband's materialistic attitude, Emily is portrayed as an artist, i.e. somebody concerned with the more elevated spiritual aspects of man. Therefore, she is charmed by the spiritual part of Islam which produced wonderful artistic civilization: 
AMIR. I don't understand what you can see in it.

EMILY. In what?

AMIR. In Islam?

EMILY. When we were in the mosque in Cordoba...remember that? The pillars and arches?

AMIR. Those were great.

EMILY. Remember what you said?

AMIR. I'm sure you're going to remind me.

EMILY. That it actually made you feel like praying.

EMILY. There's so much beauty and wisdom in the Islamic tradition, Amir.

AMIR. But the thing is? It's not just beauty and wisdom (i. 15-16).

The argument between Emily and Amir is based on their different outlooks on Islam or as Amir puts it: "Em and I don't see eye to eye on Islam. I think it's ... a backward way of thinking. And being" (iii. 50). As an artist, Emily can only see the beauty of the Islamic tradition taking no heed of its worldly part which organizes Muslims' material lives. Both art and religion care for nourishing the human soul as they deal with man not as part of nature, but as part of what is beyond nature: "the existence of another world of nature (another system) along with the world of nature is the main source of every religion and art. If there were only one world, art would have been impossible. In fact, we find a suggestion in every work of art, of a world we do not belong to... . (Begovic 142).

On the other hand, Amir is aware of the worldly part of Islam which includes God's orders to Muslims in their personal and public 
life. God's orders, mentioned in the Qur'an and Sunna, cover all fields of life i.e. political, public or personal. Amir fully realizes that Islam and secularism are two conflicting forces. He believes that man should be governed and ruled by secular thought rather than Islamic laws. Therefore, Amir keeps shocking Emily with what he believes to be the Islamic view of some issues such as violence inflicted upon women. He translates from the Qur'an:

AMIR. (Continuing): If they don't obey...Talk

to them. If that doesn't work... Don't sleep

with them. And if that doesn't work...

(Turning to Emily) Em?

EMILY. I'm not doing this.

AMIR. Beat them (iii. 56).

Amir does not provide any authorized interpretation of the text he quotes. He does not refer to the restrictions of wife-beating as it should be the last step a man takes and it should not harm the woman's body. He does not also refer to God's orders to men to take care of women, not to harm them and to meet their financial needs. ${ }^{1} \mathrm{He}$ also ignores God's order to men to treat women kindly ${ }^{2}$. Not only does he ignore the direct orders mentioned in the Qur'an, but he also turns a blind eye to Sunnah. Prophet Muhammad (Peace be upon him) says: (The best of you is the best to his wife) ${ }^{3}$ and (Women are the twinhalves of men $)^{4}$. The Prophet's advice to men to take care of women is intentionally ignored by an anti-Islamic apostate, i.e. Amir. Amir uncovers his self-loathing character as well as his biased attitude towards Islam as he says: "Islam comes from the desert. From a group of tough-minded, tough-living people. Who saw life as something hard and relentless. Something to be suffered" (iii. 51). Significantly, an apostate who expresses utter hatred for Islam, Amir acts as a Western woman-abuser who violently beats his wife on learning about her past love-affair with Isaac: 


\begin{abstract}
[All at once - Amir hits Emily in the face. A vicious blow.]

The first blow unleashes a torrent of rage, overtaking him. He hits her twice more. Maybe a third. In a rapid succession. Uncontrolled violence as brutal as it needs to be in order to convey the discharge of a lifetime of discreetly building resentment (iii. 73).
\end{abstract}

Amir's exaggerated corporal punishment of his wife reveals two main facts. First, the nonsensical allegation that violence against women is an Islamic norm is undermined because it is an anti-Islamic apostate, not a Muslim, who acts brutally against his wife. Second, Amir's act of violence against his wife reflects what the dramatist successfully calls "a lifetime of discreetly building resentment". His desperate efforts to be treated as an American citizen by attacking Islam are thrown to the wind. Commenting on the wife-beating scene, Torange Yeghiazarian argues that "the assumption here seems to be that violence towards women is the singular purview of Muslim men; a ludicrous notion easily dismissed by a quick survey of statistics on rape and spousal abuse in the U.S." (Yeghiazarian par. 12).

In his "Secularism: Its Content and Context" (2011), Akeel Bilgrami distinguishes between 'secularism', 'secular' and 'secularization'. He argues that secularism is "the name of a political doctrine" (2). He explains that "unlike the term 'secularization,' it is not so capacious as to include a stance against religion that requires redirection of either personal belief or, for that matter, any of a range of personal and cultural habits of dress or die"(3). It is rather a separation of religion and politics. Therefore, 'secularism' does not attack religion as "the slogan 'separation of church and state' ...allows one the church, even as it separates it from the state, or more generally, from the polity" (3). Bilgrami's argument provides a narrow definition of the term; it is merely separating religion from politics not 
from public or personal life. Bilgrami's concept of secularism is also found in Disgraced. The main character, Amir, argues: "I'm assuming we're all opposed to people who think the Bible is the Constitution?" (iii. 53 ) Amir's rejection is due to the fact that religion, for him, should only be confined to the spiritual world and has nothing to do with politics. The Christian principle, 'render to Caesar what is Caesar's and render to God what is God's', can never be applied to Islam. Ignoring the political side of Islam is not accepted by Muslims because it is stated in the Qur'an that those who do not rule by God's orders are infidels:

The simplest Muslim can see how Islam explains all matters in detail. It is impossible for a Muslim to feel that the religion that regulates his marital affairs, his business, his eating habits, his manner of sleeping, and even how he goes to the bathroom could ever leave managing the political and economic affairs of society to other than Allah. For Allah says "We have neglected nothing in the Book" [Surah alAn'am 38] (Al-Oadah 6).

Following God's instruction is enslaving oneself to the Biggest Power not to any minor power. Islam, though it calls for the freedom of man, rejects excessive individualism which secularism calls for. In Disgraced, Emily mentions the starting point of secularism in the Renaissance: "The Renaissance is when we turned away from something bigger than ourselves. It put the individual at the center of the universe and made a cult out of the personal ego" (iii. 44). She proceeds that Islam is against that: "that never happened in the Islamic tradition. It still more connected to a wider, less personal perspective" (iii. 44). Opposing her argument, Amir draws a comparison between Muslims and Jews:

AMIR. Desert pain. I can work with that. Jews reacted to the situation differently. They turned it over and over, and over... I 
mean look at the Talmud. They're looking at things from a hundred different angles, trying to negotiate with it, make it easier, more livable...

JORY. Find new ways to complain about it...

[Jory chuckles. Isaac shoots her a look.]

AMIR. Whatever they do, it's not what

Muslims do. Muslims don't think about it.

They submit. That's what Islam means,

by the way. Submission (iii. 52).

Amir's acceptance of the Jews' attitude in life and his attack of Muslims' submission to Almighty God stress his self-hating and selfdeluding character. While Jory, a Jew's wife, regards Jews' disobedience to God's orders as "new ways to complain", Amir claims that Jews try to make their lives easier through turning the matter over, looking at the problem from different angles and through negotiation. On the other hand, Amir, unjustly, accuses Muslims of not using their minds because they submit to God: "Muslims don't think about it. They submit". His ridiculous allegations reflect a narrow-minded character unable to understand that Muslims who do 'submit' to God, the Ever-Lasting Power, are continuously ordered by their God to 'think'. No wonder Muslims were able to establish a grand civilization at a time when Europe was steeped in darkness:

For centuries following the fall of Rome, Western Europe was backward and benighted, locked in the Dark Ages and barely able to tell the time of day... . Islamic culture, however, was thriving and had become a powerhouse of intellectual exploration and discussion that dazzled the likes of Adelard of Bath who ventured to the Near East in search of the scientific riches pouring out of the cities like Antioch, 
Baghdad or Cairo, whose libraries held hundred thousand books at a time when the best European libraries housed, at most, several dozen ("How Islamic Learning Transformed Western Civilization").

One of the most important and misleading definitions of secularism is provided by Charles Taylor who explains the term in the light of the three principles of the French Revolution i.e. liberty, equality and fraternity. In his "The Meaning of Secularism" (2010), Taylor explains the relation between secularism and liberty:

First, no one must be forced in the domain of religion, or basic belief. This is often defined as religious liberty, including of course, the freedom not to believe. This is what is also described as the "free exercise" of religion, in the terms of the U.S. First Amendment" (23).

He proceeds to the second principle: "second, there must be equality between people of different faiths or basic beliefs; no religious outlook or (religious or areligious) Weltanschauung can enjoy a privileged status, let alone be adopted as the official view of the state"(23). Regarding the third principle of 'fraternity', Taylor explains that "all spiritual families must be heard, included in the ongoing process of determining what the society is about (its political identity) and how it is going to realize these goals (the exact regime of rights and privileges)" (23). According to Taylor's concept of secularism, both religious and antireligious people could coexist happily in a secular society where there is "a move from a society where belief in God is unchallenged and indeed, unproblematic, to one in which it is understood to be one option among others, and frequently not the easiest to embrace" (Taylor, A Secular Age 3).

However, it is worthy of note that the French Revolution which attacked and rejected religion, owes its three principles to the world of values, i.e. religion not the world of matter. The materialistic 
world favours interest not values which stands in contrast to the spiritual world. To solve the dilemma, secularists believe that those principles can be carried out through law rather than faith. In Disgraced, Amir is a lawyer, a man of justice who is faced with an unexcused case of injustice concerning Imam Fareed. Imam Fareed is condemned for collecting money in the mosque for Hamas while collecting money in a church goes unquestioned. Abe, Amir's nephew, asks his uncle to attend the hearing but Amir, knowing how risky for him to defend a Muslim, shows a great deal of reluctance:

ABE. Imam Fareed didn't do anything. Every church in the country collects money. It's how they keep their doors open (i. 11).

Abe's speech highlights the biased attitude in America against Muslims. Significantly, it is not only Christians who are allowed to collect money but Jews, though a minority in the US, are also allowed to send money to a Palestinian-killing entity called Israel. Isaac mentions that Amir's boss, Steven, "is a huge fund-raiser for Netanyahu" (iii. 68).

The following dialogue between Amir and Emily reflects how liberty, equality and fraternity as secularist principles, are ignored by Amir when a Muslim's case is concerned:

Emily: I'd like to think there was some part of you that believed in what you were doing. I mean, I don't know...

Amir. No... Of course.

Emily. But when it comes to the Imam, it's like you don't care. Like you don't think he's human (i. 18).

Emily questions her husband's credibility as a man of law which forces Amir to agree on attending the hearing. However, Amir, aware that such a step cannot pass unheeded, is upset as the Times mentions 
that he supports the Imam and his identity is immediately questioned by his Jewish boss, Steven. Amir's fear of defending the Imam illuminates a two-fold fact. He does not believe in the alleged secular principles he attempts to adhere to which reflects his hypocritical character. He is also aware that the 'secular' American society shows a great deal of racism and intolerance if the cause is related to a Muslim convict. Isaac explains the effect of the event on Amir:

ISAAC. The paper mentioned the firm and they mentioned Amir and it looked like he was representing a man who was raising money for terrorists.

EMILY. That 's absurd.

ISAAC. That's not what Steven thought. He went ballistic.

EMILT. He did?

ISAAC. Don't you know this? Jory said your husband broke down. Was crying at a staff meeting. And apparently shouted something about how if the Imam had been a rabbi, Steven wouldn't have cared. Steven thought the comment was anti-Semitic (iii. 68).

Amir's hypocritical character is entirely uncovered in the above dialogue between Isaac and Emily. Suffering from an unjust treatment by his Jewish boss, Amir breaks down and asks about Steven's attitude if the Imam is replaced by a rabbi. Significantly, in a previous dialogue, Amir unjustly defends Jews and assumes a racist attitude towards Muslims. His present situation reflects how he suffers from an inferiority complex that leads him to be unjust in a biased society.

The racist attitude of the American society is made clear as Amir's Islamic background deprives him of his right to become a 
partner in the firm, the job which Jory the Afro-American obtains though Amir has "been there twice as long as she was" (iii. 67).

In his "Two Concepts of Secularism" (2000), Wilfred McClay distinguishes between two meanings of secularism. The first "can be understood as an opponent of established belief - including a nonreligious establishment - and a protector of the rights of free association" (58). Secularism, in this sense is not against religion but rather against turning it into an official authority. Second, McClay proceeds: "it can be understood as a proponent of established unbelief and a protector of strictly individual expressive rights" (58). The second meaning is anti- religious as it calls for the authorization of 'unbelief'.

Dr. Abd El Wahhab El- Mesery, in his turn, divides secularism into two types, i.e. partial and comprehensive. Partial secularism is

a partial outlook on reality as it does not deal with the universal and final (epistemological) dimensions of reality. It is not comprehensive. It calls for separating religion from politics, economics and maybe some other fields of general life... . Such an outlook does not deny the existence of ethical, human, and perhaps religious absolutes and foundations or even metaphysics..." (120).

The concept of separating religion from politics is in accord with the aforementioned definition proposed by Bilgrami. El-Mesery's argument about partial secularism is utterly rejected by faith-believers particularly, mainstream Muslims who do not believe in such a separation.

As for comprehensive secularism, El-Mesery explains that it is a comprehensive vision of the world with an epistemological dimension (absolute and final) in all fields of life. It is rational and materialistic... which considers the centre of the world embedded in the world not separate from 
or transcendent of it. The whole world mainly consists of one matter which is neither sacred nor secret but of a continuous movement of no end or goal" (120-21).

El- Mesery concludes that such a vision does not merely mean the separation of religion from the state; it is rather "an exclusion of all religious, ethical and human values that transcend the material movement and senses... ." (122). Such a comprehensive definition of secularism which excludes religion from personal life is also indicated in Disgraced. Amir rejects Islamic laws in general and unashamedly disobeys God's orders. He accepts a gift from one of his friends which is no more than a Hindu god and puts it in an obvious position in his apartment. He eats pork and drinks wine which are entirely forbidden in Islam:

AMIR. Em's making pork tenderloin. (To

Isaac) you eat pork, don't you?

AMIR: What are you drinking?

JORY: You have scotch?

AMIR: Still have the bottle of Macallan that

You gave me.

JORY. I expect more from you, Amir.

AMIR. We'll finish it tonight. On the rocks? (ii.

The aforementioned definitions of the term "secularism" reflect the ambiguity of the term; is it only political or it includes public life, is it against religion or not, does it free the individual or imprison him, is it partial or comprehensive? Such an ambiguity is more obvious in the United States, where the dramatic events of Disgraced take place. The US is regarded as "the vanguard nation of technological and social innovation" which "is also the developed 
world's principal bastion of religious faith and practice" (McClay 54). Secularism in the US is exceptional because America, unlike Europe, "never experienced ecclesiastic suppression of democracy, private enterprise, and education. Instead, in America, religion often spawned progressive ideas" (Dent 1). The First Amendment of the U.S. constitution reads: "Congress shall make no law respecting an establishment of religion, or prohibiting the free exercise thereof...". Such an Amendment establishes the US as a secular country which separates religion from the state but at the same time maintains religious freedom for its people: it "prohibits the establishment of a national religion by the Congress or the preference of one religion over another, non-religion over religion, or religion over non-religion" (http:// system.uslegal.com/u-s-constitution/amendment-i). The first Amendment sets the US as a secular country in the sense of Charles Taylor's definition. It is a claim that all citizens living in the US are free to practise their religion without forcing an established religion. In 2010 President Obama declared his happiness when Imam Feisal Abdul Rauf "proposed the building of a multi-storey Muslim cultural centre" in New York. Obama says: "This is America",..."and our commitment to religious freedom must be unshakeable (Kabir 20).

The American allegation of secular tolerance is defied in Akhtar's Disgraced in which Muslim characters have to hide their Islamic identity to keep up living in the US.; Amir and his nephew, Hussein (Abe), changed their names. The setting of the play, New York, has a significant connotation especially for Muslims living in America as it is the state in which 9/11 events took place. The events were disastrous for Muslims living in America: "after the Twin Towers attacks on 11 September 2001, the 'Muslim question' came to the fore: who are these people, what is their faith, why do some Muslims hate the West, is the American media going overboard with its representation of Muslims in America, how is Islamic visibility impacting on this group" (Kabir 5). Pakistan, Amir's mother country, 
is also of major significance because it is "one of only two modern nation-states (the other being Israel) where religion was complexly the raison d'être in the creation of the nation and a critical component of ideologies of nationhood and community" (Afzal 9). Besides, "the remapping of Pakistan within the Muslim world and the Greater Middle East in U.S. foreign policy and in post 9/11 practices of surveillance and U.S. imperialism racialized Pakistani Americans and immigrants in terms of religion" (Afzal 9).

The opening stage-direction in Disgraced which describes Amir's residence reflects secularism in the American sense where free belief is allowed. It points to a "large painting, in luscious whites and blues with patterns reminiscent of an Islamic garden"(i. 1). The colours whites and blues are not the favourite colours of Islam (green is more preferable because it is related to the clothes of true believers in heaven) but they remind the audience of the Israeli flag. Such a mixture of cultures reflects the multicultural secular US. There is also a statue of Siva, one of the Hindu gods. Moreover, the first appearance of Amir and his wife Emily seemingly shows religious liberty. Emily is described as "white, lithe and lovely, early 30s" while Amir is "South Asian origin, 40s, in an Italian Jacket, a crisp, collared shirt, but only boxers underneath, posing for his wife. $\mathrm{He}$ speaks with a perfect American accent. She sketches him" (i. 1). It is significant to note that Emily's external appearance is only described as "white" indicating race with no heed to what she wears because she stands for the majority group in the US, i.e. the WASP. Amir, on the other hand, is granted a detailed description that includes his colour, dress and his language because he stands for a minor group. He was born in the US but of non-American origin and strives to become an assimilated American citizen. The marital relationship between both of them is a sign of Amir's assimilation in the American society. However, Emily's painting of her husband is highly significant as the painting reflects the white woman's outlook on her Muslim husband, 
i.e. a mere slave. Amir seeks assimilation; therefore, he blindly approves the American outlook.

Though the first stage direction falsely denotes liberty, the first dialogue bluntly contradicts that principle. It reveals the master/slave relationship between the 'white' Emily, and the 'South Asian' Amir who exclaims: "I think it's little weird. That you want to paint me after seeing a painting of a slave" (i. 3). Amir's informative statement is significant. Despite being Emily's husband, Amir is similar to Juan de Pareija, a former slave of the famous painter, Velazquez: "Much like de Pareija, Amir wears the clothes of his masters proudly" (Yeghiazarian par. 5) by holding tight to secularism. Emily admits that she compares her husband to Pareija, in consequence of Amir's attitude towards a racist waiter in a restaurant: "You made him see that gap. Between what he was assuming about you, and what you really are" (i. 4). In other words, the waiter looks down at Amir because of his colour but when Amir talks to him using a perfect American accent, the waiter was dumbfounded. Such an incident does not only reflect the waiter's racist attitude, but also shows that Amir only gains respect once he is Americanized. Sadly, Amir accepts the racist and intolerant American attitude towards Islam; therefore, he shuns Islam and attacks it to please the Americans. Proceeding in her argument, Emily explains: "But I started to think about the Velazquez painting. And how people must have reacted when they first saw it. They think they' re looking at a picture of a Moor. An assistant" (i. 4). A "Moor" who is most likely a Muslim, shares with Amir colour and religion. Aware of the racist outlook of Americans on non-Western, Amir corrects her using one word: "A slave" which Emily does not deny: "Fine. A slave. But whose portrait-it turns out -has more nuance and complexity than his renditions of kings and queens" (i. 4).

The American Islamophobia stands in a dire contrast to the principle of equality. Therefore, Amir and his nephew, Abe, change 
their birth names to hide their religious identity. Addressed by his uncle as Hussein, his birth name, Abe protests:

ABE: Uncle.

AMIR: What?

ABE: Could you just call me - -

AMIR: I've known you your whole life as Hussein. I'm not gonna start calling you Abe now.

ABE: You know how much easier things are for me since I changed my name? (i. 8-9)

Abe makes it clear that the American society is hostile not to different races but to Islam in particular; therefore, he changes his name which tells about his religion into a Christian name so as to lead an 'easier' life in the US. Life in the US becomes difficult for Muslims after the 9/11 attacks which resulted in the US Patriot Act that "allows law enforcement agencies to use surveillance, and search and deport people suspected of terrorism - related acts" (Kabir 17-18). Amir does not only change his family name but also lies about the country his parents were born in:

AMIR: ... Steven comes in. With Jack. Sits down. Asks me

where my parents were born.

EMILY: Pakistan.

AMIR: I said India. That's what I put on the form when I got hired (iii. 29-30).

India and Pakistan were one country before the division in 1947, i.e. Amir claims that he belongs to the Indian civilization which Samuel Huntington considers one of the seven civilizations in the world. After the division, Pakistan became "a homeland for Indian Muslims" (Nasr 24) and "Islamism has grown strongest and has had its most 
profound political impact" (Nasr 24). Besides, a famous statement of the founder of Pakistan, Muhammad Ali Jinnah reads: "Pakistan is liberated to become a laboratory of Islam" (Zafar 165). Therefore, Amir hides his origin in order to pass for an Indian not for a Pakistani Muslim. He hides his Islamic identity for two main reasons. First, he agrees with his nephew that it is easier for him to live in the US if he hides his Islamic identity. His fear of being known as a Muslim is excused because Muslims, according to Yvone Haddad, were not justly treated in the US:

Throughout the history of America different groups have played the role of outsider, non-participant, even enemy, in response to which Americans can reaffirm their identity as a nation standing for the right and the good. Currently, Muslims appear to be the victims of the apparent need to create such an enemy, one that can be defined as the antithesis of the national character and a threat to the righteous order (23).

Haddad criticizes the American policy which turns Islam into an enemy and describes how difficult for a Muslim to live in the US:

living as a minority in a dominant culture often hostile to Islam, Muslims are often alienated and powerless. They are confused and challenged by an America in which, despite separation of church and state, Christian values are assumed to be integral to American identity and values" (Esposito, 4).

The second reason for which Amir changes his name is selfhatred. He rejects Islam and the Quran which he regards as "one very long hate-mail letter to humanity" (iii. 52). As Ghazala Hayat argues: "Amir is self-loathing, negates the practices of Islam, and finds faults with the beliefs of the faith" (A 10). The second reason is also related to the first one because "when you are a minority and see your faith being labeled in a negative way, you might believe unconsciously that 
attacking your own faith will shield you from negativity. You might become "friends with and belong to the inner circle" of the majority" (Hayat A10). Therefore, Amir attacks what he claims to be the intolerance of Islam which opposes the 'tolerance' of secularism. $\mathrm{He}$ talks about his mother's opinion of Jews and the general outlook of Muslims on white women to prove his point. He criticizes Islam because of the behavior of some Muslims, but does not refer to God's orders stated in the Glorious Qur'an, to Muslims to be forgiving, just, honest...etc.

As Abe states that the Imam is not a bigot but just likes Amir because Amir is a Muslim, the latter declares that he is no more a Muslim but an apostate. Amir is aware that Islam rejects secularism and secularists, who in their turn, attack Islam in particular. Amir criticizes Islam because it opposes the political definition of secularism, i.e. the distinction between state and religion: "In Islam there's no difference. There's no distinction between church and state" (iii. 53). The use of 'church' instead of 'mosque' indicates that Amir is unable to understand the difference between Islam and Christianity that Salman Al-Oadah explains. He illuminates his point through another comparison: "I'm assuming we're all opposed to people who think the Bible is the Constitution?" (iii. 53) The use of the plural subject pronoun 'we' is significant because it manifests Amir's desperate attempt to be only treated as an American citizen. Amir refers to the political meaning of secularism i.e. the "separation of the public and private spheres and in particular the separation of religion and state" (Hashemi 106). He criticizes the Islamic outlook on politics as he is well-aware that those Muslims who defend such an Islamic outlook are labeled as "fundamentalists, connoting that they are all rigid, antimodern, backward zealots who want to implement an Islamic state" (Esposito 148). Jory, the Afro-American woman and Amir's colleague, attacks those who treat the constitution as the Bible: "What gets me just as people who treat the Bible like the Constitution 
are the people who treat the Constitution like it's the Bible" (iii. 54). Jory unconsciously defends Islam which does not make a distinction between state and religion. If God's orders are regarded as inconvenient while God knows everything, capable of doing whatsoever, and is lasting, it is much more inconvenient to deal with man-made laws and rules as sacred.

It is also noteworthy that Isaac, the Jew who has no problem in declaring his Jewish identity in a Christian country, exclaims to Amir: "You're saying Muslims are so different. You're not that different. You have the same idea of the good life as I do" (iii. 54). What Isaac means by 'the good life' is the secular attitude adopted by Amir and himself. However, Amir's attacks of Islam rather than any other religion do not only illuminate his inferiority complex but also uncover his untenable position as secularism is meant to underestimate religion in general. He keeps criticizing Islamic instructions to satisfy his secular companions. He mentions the punishment of those who renounce their faith in Islam, wife beating and other laws in Islam that he condemns. He directly paraphrases from the Quran without providing his own understanding or referring to authorized explanations. His unreasonable argument might better be understood in the light of Elizabeth Hurd's explanation of two types of secularism; the first is "laicism, or the attempt to expel religion from public life" (115) while the second is what she calls "JudeoChristian secularism, in which sacred aspects of Judeo-Christianity quietly inform public discourse and practice" (115) Hurd proceeds that "both of these varieties of secularism are extremely unsympathetic toward the Islamic religion. Both chastise Islamic activists for attempting to import their religion into a would-be secular (either laicisit or Judeo-Christian) democratic public sphere" (115).

In Disgraced, the heated dialogue that takes place in Amir's house mainly revolves around Islam. Each character, Antoun Issa argues, "is deeply entrenched in their respective position - Amir 
maintaining a hostile, radical view of Islam, while Emily forming a moderate, appreciative stance - and spends a significant portion of the play attempting to convince the other of the true Islam" (Issa par. 2). Isaac, in his turn serves "as a provocateur in drawing out Amir's deepest and darkest opinions on issues related to political Islam" (Issa par. 2). Jory, Amir's competitor in the firm, supports the unfair measures taken by France against Muslims.

The debate can better be understood in the light of Samuel Huntington's theory of the clash of civilization in which he argues that the main conflict that came into being with the end of the cold war is the conflict of civilizations:

Civilizations are differentiated from each other by history, language, culture, tradition and, most important, religion. The people of different civilizations have different views on the relations between God and man, the individual and the group, the citizen and the state, parents and children, husband and wife, as well as differing views of relative importance of rights and responsibilities, liberty and authority, equality and hierarchy (25).

Religion, according to Huntington, is the most important factor in any civilization. Therefore, in Disgraced, the dialogue between the four main characters might be regarded as a clash of civilizations in which the main target of hostility and attack is the Islamic civilization. Significantly, they discuss the issues which arouse suspicions about Islam such as the woman's veil. Everyone of them provides his/her own secular view of the issue, i.e. Islam is evaluated from secularist views. Jory is an Afro-American woman not a WASP like Emily. Similar to Amir and Isaac, she belongs to a minority group in the US but her efforts to merge in the American society are far more successful than those of Amir's. She approves the violent measures which France, one of the most famous secularist countries in the Western world, takes against the Islamic veil: 
JORY: (Suddenly impassioned): No. See.

Sometimes you just have to say no. I

don't blame the French.

ISAAC: The French?

JORY: For their problem with Islam.

ISAAC: You're okay with them banning the veil?

JORY: You do have to draw the line somewhere.

ISAAC: Okay, Mrs. Kissinger.

EMILY:Endearing

ISAAC: I'm married to a woman who has a Kissinger quote above her desk in the den...

JORY: "If faced with choosing justice or order. I'll always choose order" (iii. 57).

Jory's double-standard philosophy illuminates her biased outlook on Islam. In a previous speech she refuses treating the constitution as the Bible because time changes and old laws should not be applied to the present. As far as an Islamic law is concerned, namely, the veil, Jory approves banning the veil in France because the veil is against the secular principles France adopts. Banning the veil in French schools is unjust because it defies one of the principles of the French Revolution, i.e. liberty. In Disgraced, Isaac, the Jew, argues that the veil is sometimes the woman's choice: "I happen to know a few very brilliant Muslim women who choose to wear the veil" (iii. 59). Choice means freedom which should be maintained in a secular society. John Esposito explains what the veil means for many Muslims: 
The [Islamic] dress has multiple meanings: it asserts a new public morality rooted in Islamic rather than Western values, commands respect from men, encouraging them not to focus on physical attraction and to treat women as persons and professionals rather than sex objects, and communicates national pride and resistance to Western cultural dominance as well as resistance to authoritarian regimes (153).

However, Jory answers back that it is a sign of oppression: "The veil is evil. You erase a face, you erase individuality. Nobody's making men erase their individuality. Why's it always come down to making the woman pay?" Jory expresses a stereotypical Western outlook on Muslim women as "in American photographs of the Middle East, women were five times (42) percent more likely to be portrayed as victims than were men ( 7 percent)" (Esposito 150). Therefore, the woman subject is always highlighted in cultural wars and is deployed to stigmatize Islam as a religion oppressing women. In order to be an open-minded citizen in an unjust society, a Muslim has to feel ashamed of his own faith:

In many countries government policies designed to control the Muslim community, to "domesticate" Islam, have put pressure on Muslims not simply to integrate into a multicultural society but to assimilate by abandoning elements of their Muslim belief and culture in order to enjoy full participation in their country (Esposito 161).

The arrest of the Imam, in Disgraced, is not the only incident that reflects the bias against Islam but Abe's friend, Tarek was also arrested on expressing his opinion about the US. Such a bias throws the claimed principles of secularism to the wind. Therefore, Abe restores his Muslim name, i.e. Hussein and is dressed in an Islamic dress. Amir finally uncovers the myth about the American intolerant secularism as he advises Abe: "you need to understand that it's not a 


\section{_Doaa Essam Abdel Hakim: The Conflict between Secularism and Islam 31}

neutral world out there, Not right now, Not for you. You have to be mindful about sending a different message" (iv. 79). Amir's failure to lead a good life in America is summarized in Abe's words:

The one thing I can be sure about with you? You'll always turn on your own people. You think it makes these people like you more when you do that? They don't. They just think you hate yourself. And they're right! You do! I looked up to you. You have no idea-(iv. 81).

\section{Conclusion:}

Disgraced uncovers the conflict between Islam and secularism through its four characters, Amir being the theme-carrier. A selfdeluded Amir lives in America on a false assumption that "regardless of your race and religion, if you work hard and pay your dues, at some point you will get the promotion and as a result, the respect of your colleagues" (Yeghiazarian par. 10). However, Islam and secularism in the US are two poles as made clear in the above analysis. That conflict is mainly based on the false Western outlook on Islam which accuses Islam either of materialism or of primitivism. In his introduction to Begovic's Islam between the East and the West, El - Mesery argues: "religiously (the mere spiritual), Islam is accused of being closer to nature and reality than it should be and that it copes with real life" (25). In other words, Islam is regarded by secularists as more worldly than it should be. "Scientifically", El-Mesery proceeds, "Islam is accused of containing religious and metaphysical elements." In other words, it is against science and progress. El-Mesery concludes that "in fact, there is only one Islam that is similar to the human being; both have soul and body" (25).

Islam, in its turn rejects secularism politically and socially. As far as the separation between religion and state is concerned, Islam and secularism are contrasting ideologies: "In the West, the notion 
that religion should guide society was weakened during the Renaissance, dealt a crushing blow in the Age of Enlightenment and drew its last gasp as the French Revolution put a dramatic end to the" divine right of kings" (Noakes 57). Greg Noakes argues: "If Muslims are to develop, the secularists argue, Islam must be relegated to the private sphere and rational human allowed to guide society" (57). In explaining Begovic's theory, El Mesery argues: "we cannot confine Islam to its religious Sofi part and ignore its political part. Otherwise, imitation and submission will be focused" (25). El Mesery proceeds that "the religious (spiritual) component of Islam cannot be ignored too or it will be considered a silent refusal of ethical duties. True Islam is not a mere spiritual religion or a way of life but a method and a principle of organizing the universe rather than a ready solution" (25-6).

Amir's attempts to please the Americans by attacking Islam are thrown to the wind as the dramatist explains:"it does not matter what his thoughts on Islam are; in a post-9/11 world, those nuances are lost"(Nestruck par. 5). His tragedy is due to the fact that he "does not live in a world of self-acceptance" (Allen 18). 
—Doaa Essam Abdel Hakim: The Conflict between Secularism and Islam 33

\section{Notes}

ا. قال تعالى: (الرجال قو امون على النساء بما فضل الله بعضهم على بعض وبما أنفقوا

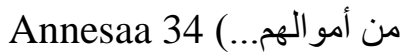

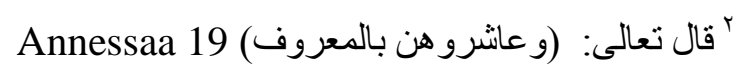
كآ قال رسول الله صلى الله عليه وسلم: (خيركم خيركم لأهله) Sunan A-Tirmidi) قُال رسول الله صلى الله عليه وسلم: (النساء شقائق الرجال) Musnad Ahmed 


\section{Works Cited}

Afzal, Ahmed. Lone Star Muslims: Transnational Lives and the South Asian Experience in Texas. New York: New York University Press, 2015, Print.

Akhtar, Ayad. "Disgraced". American Theatre. Vol 30. Issue 6, JulyAugust 2013. Online Research Library: Questia Reaeder. Web.

Allen, Kathleen. "'Disgraced' Confronts Attitudes toward Islam, Sense of Self. AZ Daily Star. Oct.15, 2015, 18. Print.

Al-Oadah, Salman B. "Islam and Secularism." Web. File:C./Users/dell/Downloads/secularism.pdf

Begovic, Aly Ezzat. Islam between East and West. (1994) Trans. Muhammad Yussef Adss. Cairo: Dar Al-Shorouk, 2016, Print.

Bilgrami, Akeel. "Secularism. Its Content and Context." Social Science Research Council. October, (2011), 1-35.

Dent, George W. Jr. "Secularism and the Supreme Court." Brigham Young University Law Review. January 1, (1999), p.1+.

Ebrahinian, Sakineh R. "Secularism and Islam." Journal of Social Issues \& Humanities. Vol. 3 Issue 1, January (2015), 110-13.

El - Mesery, Abd El-Wahhab. $\quad$ Forward. Begovic. Trans. Doaa Essam El- Mesery, Abd El-Wahhab \& El-Admah, Aziz. Secularism under the Microscope. Trans. Doaa Essam Beirut: Dar El-Fekr El Moasser, 2000, Print.

Esposito, John. The Future of Islam. New York: Oxford University Press, 2010, Print.

Feldberg, Robert. "A Compelling Beginning Dissolves into Chaos. The Record. NJ, Oct. 23. (2102), BL 1.

Haddad, Yvonne Yazbeck ed. The Muslims of America.New York: Oxford University Press, 1993.

- - - Muslims on the Americanization Path? John L. Esposito (ed.) NewYork: Oxford University Press, 2000. 
—Doaa Essam Abdel Hakim: The Conflict between Secularism and Islam 35

Hashemi, Nader. Islam, Secularism, and Liberal Democracy: Toward a democratic Theory of Muslim Societies. New York: Oxford University Press, 2009, Print.

Hayat, Ghazala. "Faith Perspectives." "Disgraced" Explores Faith and Self-Loathing." St. Louis Post-Dispatch. (MO) Feb. 2, (2016): A10.

"How Islamic Learning Transformed Western Civilization." Review of 'The House of Wisdom' by Jonathan Lyons. Muslim Heritage. Web. 13 Oct. 2018

Huntington, Samuel P. "The Clash of Civilizations?"Foreign Affairs. Vol. 72. No. 3, (Summer 1993): pp.22-49. Print.

Hurd, Elizabeth. "The International Politics of Secularism: US Foreign Policy and the Islamic Republic of Iran." Alternatives: Global, Local, Political. (March-May 2004): 115. Print.

Issa. Antoun. "'Disgraced' Exposes the Contradictions of Identity. Middle East Institution. May 13, (2016): n.p. Web.

Kabir, Nahid Afrose. Young American Muslims: Dynamics of Identity. Edinburgh University Press, 2013. Print.

McClay, Wilfred M. "Two Concepts of Secularism." The Wilson Quarterly. (Summer 2000): pp 54-71. Print.

Nasr, Vali. "Blurring the Line: Islam and Politics in South Asia." Harvard International Review. Vol. 18. Issue: 3, (Summer 1996): pp. 24-27, 78-79. Print.

Nestruck, J. Kelly. "Ayad Akhtar on Islam in America and His 'Prescient' Drama, 'Disgraced'." The Globe and Mail. March 24, (2016): n.p.

Noakes, Greg. "Issues in Islam: Secularism and the Islamist Challenge." Washington Report on Middle East Affairs. October 31. (1993): 57+. Print 
Taylor, Charles. A Secular Age. Cambridge: The Belknap Press Harvard University Press, 2007. Print

"The Meaning of Secularism." The Hedgehog Review. Fall (2010): 23-34. Web.

Wald, Kenneth D., and Allison Calhoun-Brown. Religion and Politics in the United States. Lanham: Rowman \& Littlefield, 2014. Print.

Yeghiazarian, Torange. $\quad$ "On Ayad Akhtar's Disgraced." I. Vol.2, Spring 2016. Web (1/8/2017)

Zafar, Muhammad Imtiaz. "Can Pakistan Be a Secular State?" South Asian Studies. January - June, (2013): 165+. Print 